\title{
PO SPOWIEDZI
}

Psalm 32.

a.

Szczesśliwy, któremu odpuszczona nieprawość, którego grzech jest zakryty.

Szczęśliwy człowiek, któremu winy PAN nie zalicza, w którego duchu nie ma obłudy.

Dopókim milczal, więdły me kości od jęków żalnych, jakiem co dnia wznosił.

Albowiem dzień i noc ciążyła na mnie Twa ręka i siła moja słabła, jak od skwarów letnich.

Tedy wyznalem Tobie swój grzech i nie ukrywalem swej winy przed Toba. Wyznam - rzekłem - PANU swą nieprawośé, a Tyś mi darowal winę grzechu.mego.

Niech przeto tak do Ciebie się modli człowiek pobożny $w$ chwilach ucisku, a gdy toń morska $\mathrm{z}$ brzegów wystąpi, fale do niego nie dotrą. Tyś moją osłoną, Ty od niedoli mnie chronisz, Ty mnie radością poisz zbawienia.

b.

Poucźę cię i wskażę drogę, którą iść winieneś, doradca twym będę, zwrócę Swe oko na ciebie. Ale nie bądźcie jak koń, jak muł bez rozumu, których swawolę się kiełza uzda i wędzidłem, bo inaczej nie chcą zbliżyć się do ciebie.

Uciski liczne czekają bezbożnych, a ufający PANU jest otoczony milością. Weselcie się W PANU, radujcie șę, sprawiedliwi, śpiewajcie głośno wszyscy, których serca prawe!

Psalm 32 - według Wulgaty 31 - nalėzy do psalmów pokutnych, które dawniej w chórze odmawiano w okresie Wielkiego Postu. Psalmy te były, jak o tym świadczy Possidiusz, ulubioną lekturą św. Augustyna, których ich kopię kazał sobie powiesić nad łóżkiem, aby oko jego codziennie wpatrywało się w słowa skruchy i pokuty.

Prawdopodobnie psalm pochodzi z czasów Dawida (ok. roku 1000), lecz należy przypuszczać, że tylko jego pierwsza część pochodzi z tak 
dawnej epoki, mianowicie wiersz 1-7, natomiast część drugą (w. 8-11) o charakterze pouczającym dodano później; kiedy się lubowano w podobnych ogólnych sentencjach.

Psalm jest cytowany przez św. Pawła w liście do Rzymian 4, 6. Apostoł odgadł doskonale treść dogmatyczną psálmu, mianowicie, że według nauki psalmisty dostępuje człowiek odpuszczenia grzechów li tylko z łaski Boga, że uozynki pokutne mają jedynie znaczenie przygotowawcze. Oto słowa Pawłowe: ,Kto nie ma uczynków, ale wierzy w Tego, który usprawiedliwia grzesznika, temu wiara za usprawiedliwienie policzona zostanie. Tak samo i Dawid szczęśliwym nazywa człowieka, któremu Bóg przyznaje usprawiedliwienie bez uczynków, piszac:

Szczęśliwi, którym odpuszczono nieprawości,

których grzechy zakryte;

szczęśliwy człowiek, któremu grzechu Pan nie zalicza".

Wiara w odpuszezenie grzechów to myśl główna utworu Dawidowego. Jahwe grzechy odpuszcza i je zakrywa, by Jego oko ich nie widziało, a gdy już raz przebaczył, już żadn̨ej winy człowiekowi nie wspomina. Ale jeden warunek o rozgrzeszeniu decyduje: by grzesznik był szczerym wobec siebie samego, by - jak mówi psalmista - nie miał obłudy, nieszczerości, w sercu swoim i śmiał się przyznać do swego upadku. Tę samą myśl znajdujemy u św. Jana w jego pierwszym liście $(1,8)$. Słowa te sa trafnym komentarzem do naszego psalmu. Pisze on bowiem: „Gdy móvimy, że grzechu nie mamy, sami siebie oszukujemy i nie ma w nas szczerości. Gdy nasze grzechy wyznajemiy, (Bóg) wiernym $i$ sprawiedliwym się okazuje, odpuszcza-nam grzechy i oczyszcza od wszelkiej nieprawości".

Konieczność spowiedzi - dziś nieraz niezrozumiana - wyraźnie zaznaczona jest kilkakrotnie w pismach Starego Przymierza. Księga Przypowieści np. głosi $(28,13):$,Kto ukrywa przewiny swoje, nie zazna szcześcia, a kto je wyznaje i ich sie wyrzeka, ten milosierdzia dostapi“. Spowiedź jest taki̇e potrzebą natury ludzkiej, która pragnie wyznać swą winę wobec siebie samego i wobec Stworzyciela i Stróża wszelkiej etyki. Dlatego tė̇ w wielu innych religiach wyznawanie grzechów było praktykowane, szczególnie w Egipcie i częściowo także w Babilonii. Uczony włoski, prof. Pettazzoni, wydał dwutomową monografię p. t. La confessione dei peccati, w której zestawił cały materiał historyczno-religijny, dotyczący wyznawania grzechów w poszczególnych religiach, a dowodzący, że wszędzie psychika ludzka domaga się spowiedzi, celem zrzucenia $z$ siebie ciężaru winy. 
Autor psalmu 32 nie posługuje się utartymi religijnymi frazesami, opisuje samodzielnie walkę duchową, którą osobiscie przeżywał. Tym szczęśliwym człowiekiem, który zrzucił brzemię z sumienia swego, jest on sam. Utwór jego jest zwierciadłem jego duszy i walk, jakie dłuższy czas z sobą staczał. Później to samo będzie przeżywał autor księgi Joba. W ogóle wielkie jest podobieństwo między mýlami psalmu a rozważaniami mędrca $\mathrm{z}$ ziemi Hus. Prawdopodobnie tak samo, jak Job i psalmista cierpi fizycznie, znajduje się w nędzy i niedoli, kości jego więdną. a silły słabną, bo czuje nad sobą ciężką rękę Boga. Z początku żali się i skarży, bo czuje się przez Boga pokrzywdzonym, że cierpi niesprawiedliwiè. Nie wyciaga zrazu $\mathrm{z}$ niedoli wniosku koniecznego, że i sam jest przyczyną zesłania chłosty Bożej. Boryka się z sobą, miłość własna i ambicja stoją na przeszkodzie, by uderzyć się w piersi i wyrzec słowo: mea culpa. Dlatego ,milczy" tak długo, aż wreszcie przełamał upór swój i postanowił sobie: „Wyznam Jahwie nieprawość swoja“. Szczerze przyznał się do winy, nie taił niczego, i w tym momenoie Pan mu darował przewiny i przywrócił mu także dawne dni szczęśliwe. Ta ostatnia myśl nie jest wprawdzie wyraźnie wymieniona, ale, wynika z kontekstu i $z$ wiary autora.

Ten dodatkowy moment, to łączenie rozgrzeszenia z przywróceniem zdrowia i szczęścia nas nieco razi, ale przypomnijmy sobie, że jeszcze jesteśmy w epoce Starego Testamentu, gdzie obok promieni światła są także cienie. Zbyt często łączono grzech z cierpieniem i zbyt często żałowano za grzechy, by się uwolnić od nieszczęść. Lecz czy i dzisiaj chrześcijanin tak samo nie łączy przyczynowo tych dwóch pojęć? Jest to jakoby beżpośrednia reakcja ludzkiego sumienia, reakcja w świetle ewangelii nie całkiem słuszna. Stąd też Pan Jezus przeciw takiemu postawieniu kwestii wyraźnie protestuje. Pierwszy raz u Łukasza 13, 4: „Sądzicie - oświadcza Jezus żydom - ze galile jczycy (którzy zginęli z ręki Piłata) byli grzesznikami wiẹkszymi od innych, ze tyle cierpieć musieli. Nie, mówię wam, a jeżeli wy się nie nawrócicie, tak samo zginiecie“. Wyraźniej po raz drugi u Jana 9, 20 przy uzdrowieniu ślepego od urodzenia. Uczniowie się zapytali. Rabbi, kto zgrzeszył: on czy jego rodzice, iż narodził się ślepy? ,A Jezus odpowiedziat: Ani on nie zgrzeszyt, ani jego rodzice, lecz to siẹ stato, by dziatanie Boze na nim się okazato".

Cóż dziwnego, że nie mamy jeszcze w psalmie wyżyn Nowego Testamentu? Ale autor naprawdẹ zasługuje na naszą sympatię. Nie jest samolubem, jest altruistą, który bardzo się czuje bliskim braciom swoim. To jego wielkie przeżycie, ta wywalczona w długim zmaganiu 
się wiara, że wyznanie winy pociąga za sobą jej odpuszczeniè, nie ma pozostać tajemnica jego serca. On tej prawdy, może skądinąd już znanej, ale teraz w całej pełni zrozumianej, bo w duszy własnej przeżytej, udziela innym i ich zachęca, by w chwilach zmartwień i utrapień badali swe sumienie i z szczerym wyznaniem winy do Boga się zwracali, aby ich uwolnił od grzechu i wybawił $z$ niedoli, by nie tracili nadziei, chociażby ,morze wielkie $z$ brzegów wystapito" i kraj zalało, bo fale wzburzone nie dosięgną wiernych, którzy ze skruchą i żalem do Jahwy się modlą.

Uczucie wdzięczności wzbiera w autorze i wywołuje w nim okrzyk radości. Stwierdza uroczyście, iż nosi w duszy najgłębsze przekonanie o stałej opiece Boga nad jego życiem. Fo nie słowa zapożyczone 'skądinąd, to jego własne najosobistsze przeświadczenie, że Jahwe jest dlań osłoną i schromieniem i radością życia. Oto obraz duszy, która czuje się pewną làski Boga i patrzy w przyszłość $z$, bezwzględną ufnością.

Inny autor inspirowany uzupełnił psalmiste, dodając cztery nowe wiersze (8-11). Nie ma w nich odozucia bezpośredniego, brak momentu lirycznego, który stanowi urok pierwszych 7 wierszy, są to raczej myśli ogólnie znane, zasady religijne nieraz przēz ,mędrców“ powtarzane. Alé przyznać trzeba, że są trafnie dobrane jako uzupełnienie moralno-praktyczne pierwszej czéści, bo zacheccaja do unikania przewin, do chodzenia droga doskonałości pod kierownictwem samego Boga i walki z własną wolą. Trafnie wiersz' 9 uwydatnia, że wola ludzka skłonna jest do swawoli, że człowiek swym usposobieniem krnąbrnym zbliżony jest do mułu czy konia, że sam sobie winien nałożyć uzdę i wędzidło.

Wiersz ostatni jest prawdopodobnie jeszcze późniejszym dodatkiem liturgicznym, zaprowadzonym jako zakończenie psalmu, gdy go śpiewano $\mathrm{w}$ czasie nabożeństwa.

Psalm 32 jest piękną modtitwą dziękczynną po spowiedzi św., bo wzmacnia w nas wiarę, iż Bóg naprawdę nam grzechy odpuszcza. $Z$ jakim przejęciem kiedyś psalm ten odmawiano, gdy jeszcze nieznana była przypowieść o synu mairnotrawnym, gdy jeszcze świat nie znał słów Chrystưsowych: ,,którym odpuścicie grzechy, będą odpuszczone“! Myśli psalmów i nauka ewangelii uzupelniają się doskonale. Ich połączenie dopiero daje całość harmonijną. 